\title{
Identification and characterization of SSR, SNP and InDel molecular markers from RNA-Seq data of guar (Cyamopsis tetragonoloba, L. Taub.) roots
}

Omika Thakur ${ }^{1}$ and Gursharn Singh Randhawa ${ }^{1,2^{*}}$ (D)

\begin{abstract}
Background: Guar [Cyamopsis tetragonoloba, L. Taub.] is an important industrial crop because of the commercial applications of the galactomannan gum contained in its seeds. Plant breeding programmes based on markerassisted selection require a rich resource of molecular markers. As limited numbers of such markers are available for guar, molecular breeding programmes have not been undertaken for the genetic improvement of this important crop. Hence, the present work was done to enrich the molecular markers resource of guar by identifying high quality SSR, SNP and InDel markers from the RNA-Seq data of the roots of two guar varieties.
\end{abstract}

Results: We carried out RNA-Seq analysis of the roots of two guar varieties, namely, RGC-1066 and M-83. A total of 102,479 unigenes with an average length of 1016 bp were assembled from about 30 million high quality pair-end reads generated by an Illumina HiSeq 2500 platform. The assembled unigenes had 86.55\% complete and 97.71\% partially conserved eukaryotic genes (CEGs). The functional annotation of assembled unigenes using BLASTX against six databases showed that the guar unigenes were most similar to Glycine max. We could assign GO terms to 45,200 unigenes using the UniProt database. The screening of 102,479 unigenes with MISA and SAMtools version 1.4 softwares resulted in the identification of 25,040 high-confidence molecular markers which consisted of 18,792 SSRs, 5999 SNPs and 249 InDels. These markers tagged most of the genes involved in root development, stress tolerance and other general metabolic activities. Each of the 25,040 molecular markers was characterized, particularly with respect to its position in the unigene. For $71 \%$ of the molecular markers, we could determine the names, products and functions of the unigenes. About $80 \%$ of the markers, from a random sample of molecular markers, showed PCR amplification.

Conclusions: We have identified and characterized 25,040 high confidence SSR, SNP and InDel molecular markers in guar. It is expected that these markers will be useful in molecular breeding programmes and will also be helpful in studying molecular mechanisms of root development, stress tolerance and gum synthesis in guar.

Keywords: RNA-Seq, Molecular markers, Simple sequence repeats, Single nucleotide polymorphisms, Insertions and deletions, Marker-assisted selection

\footnotetext{
* Correspondence: SHARNFBS@IITR.AC.IN:

GURSHARNRANDHAWA@GMAIL.COM

'Department of Biotechnology, Indian Institute of Technology Roorkee,

-247667, Roorkee, Uttarakhand, INDIA

${ }^{2}$ Present address: Department of Biochemistry \& Biotechnology, Sardar

Bhagwan Singh University, Balawala, Dehradun, Uttarakhand 248161, India
}

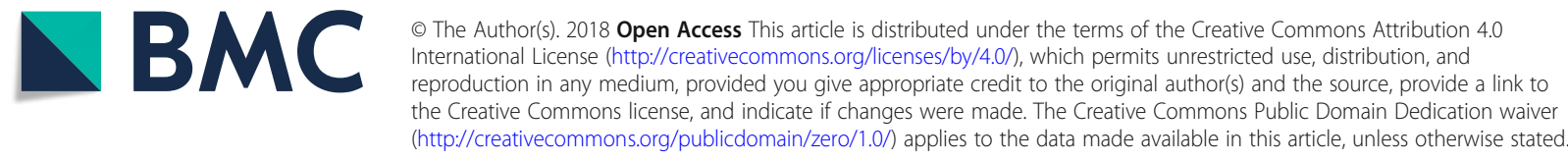




\section{Background}

Guar [Cyamopsis tetragonoloba, L. Taub.] is a diploid, annual and drought-tolerant leguminous crop mainly cultivated in the semi-arid areas of India, Pakistan and the United States of America. It is generally grown in marginal soils having nitrogen and water deficiencies and often containing high salt concentrations. Traditionally grown for fodder, green manure and vegetable purposes, guar has recently been recognized as an important industrial crop because of the presence of gum in its seeds [1, $2]$. The guar gum, which is mainly galactomannan, is a natural thickener used in petroleum, food, paper, textile, cosmetics and pharmaceutical industries [3]. It has also shown a potential in the treatment of diseases like irritable bowel syndrome, diarrhea, high cholesterol and diabetes [4-6]. Due to the high demand of guar gum all over the world, improved varieties of guar, having increased amounts of high quality gum and also able to grow under adverse conditions, have become a necessity.

The plant breeding programmes based on marker-assisted selection require the availability of a large number of molecular markers for gene tagging, genetic mapping and map-based cloning of important genes [7, 8]. Six molecular markers, namely, random amplified polymorphic DNA (RAPD), ribosomal DNA (rDNA), inter simple sequence repeat (ISSR), sequence characterized amplified region (SCAR), simple sequence repeat (SSR) and single nucleotide polymorphisms (SNPs) have been identified in guar [9-17]. The last two markers, namely, SSRs and SNPs, are considered very important for genetic mapping and plant breeding programmes [18]. Insertions and deletions (InDels) have been also found to be very valuable markers in the plant breeding programmes [19]. As the guar genome has not been sequenced, fewer SSR and SNP markers, are available for guar as compared to those available in other well-studied legume crops like soybean, Lotus, Medicago, pigeonpea and chickpea [20-25]. Therefore, further research is needed to generate a large number of SSR, SNP and InDel markers for guar.

The sequencing of cDNA pools obtained from RNA samples from various tissues, using the next generation sequencing (NSG) technique, provides a large collection of expressed sequences. This approach, called RNA-Seq technology, can be used for generating SSR and SNP molecular markers $[26,27]$. The molecular markers, thus generated, are likely to show more transferability than the other markers because of their presence in the genomic regions that are more conserved [28]. The RNA-Seq approach has been successfully used to generate SSR and SNP molecular markers in guar [16, 17]. However, the number of the markers obtained is still far less than those available in the other legumes, for which the complete genomic sequences are available.
Moreover, there is only one report of SNP identification in guar [16] and in the report the characterization of identified SNP markers has not been done. The SNP markers need thorough characterization for their appropriate and efficient use. The breeding programmes for obtaining improved varieties of guar had limited success so far because of the shortage of useful molecular markers. Hence, the present work was started with the objective of identifying and characterizing SSR, SNP and InDel markers from the root tissue of guar to enrich the molecular marker resource of this important industrial crop. The root tissue was selected as the root specific processes are considered of particular importance in the abiotic stress responses of plants [29]. The two varieties, namely, RGC-1066 and M-83 having contrasting characters were selected for this work as these were expected to show significant genetic differences.

\section{Results}

RNA seq and De novo transcriptome assembly of guar root

The RNA-Seq of roots of guar varieties RGC-1066 and M-83 by the Illumina HiSeq 2500 sequencing platform generated 29,623,208 and 29,853,028 raw pair-end reads, respectively. The data summary of the guar root transcriptome assembly has been presented in Table 1 . The $\% \mathrm{Q}>30$ and \% GC for RGC-1066 and M-83 varieties were about 87 and about 44, respectively. The numbers of clean reads generated after trimming adaptors and removing low quality bases were 17,305,480 and $17,517,086$ in guar varieties RGC-1066 and M-83, respectively. The \% Q > 30 and \% GC of clean reads of RGC-1066 and M-83 varieties were 97 and 44, respectively (Table 1 ). The de novo assembly of clean reads by Trinity program generated 1,22,206 contigs. The mean $\%$ GC of unigenes was 40 and the longest unigene was $16,844 \mathrm{bp}$. The clustering of assembled contigs using CD-HIT version 4.5.4 generated 1,02479 unigenes, with

Table 1 The data summary of de novo transcriptome assembly of guar root

\begin{tabular}{lll}
\hline Sample name & RGC-1066 & M-83 \\
\hline No. of raw reads & $29,623,208$ & $29,853,028$ \\
No. of bases/Mb & 2962.32 & 2985.3 \\
GC \% & 44.89 & 44.435 \\
Q_30 & 86.755 & 87.67 \\
Read length & $100 \times 2$ & $100 \times 2$ \\
No. of clean reads & $17,305,480$ & $17,517,086$ \\
No. of bases/Mb & 1612.14 & 1637.48 \\
GC \% & 44.27 & 43.625 \\
Q_30 & 97.345 & 97.51 \\
Read length & $100 \times 2$ & $100 \times 2$ \\
\hline
\end{tabular}


mean \% GC of 39.82 and longest unigene 16,844 bp (Additional file 1: Table S1). The sequence length and GC content distributions of assembled unigenes before and after CD-HIT are shown in Fig 1a, b. The lengths of 51,229 unigenes were $<500$ bp whereas 51,250 unigenes had the lengths more than $500 \mathrm{bp}$. A total of 32,949 unigenes had over $1000 \mathrm{bp}$ and 1297 unigenes over $5000 \mathrm{bp}$ lengths. The average length and N50 value of the unigenes were $1016.62 \mathrm{bp}$ and $1907 \mathrm{bp}$, respectively (Table 2). The unigenes assembly had $86.55 \%$ complete and $97.71 \%$ partial conserved eukaryotic genes (CEGs) against the 248 CEGs as reference (Additional file 2: Table S2).

\section{Functional annotation of guar root transcriptome}

The functional annotation of assembled unigenes of guar root was done using BLASTX against NCBI, UniProt, Pathway, Nt, Pfam and Uniref90 databases, with an E-value cutoff $1 \mathrm{e}^{-5}$ and \% identity cutoff 40 . A total of 54,249 unigenes were found to have at least one significant hit in UniProt and NCBI databases (Fig 1c). For the remaining 38,965 unigenes, no BLASTX hits were recorded. The top BLASTX hits of unigenes showed that $45.65 \%$ guar unigenes had maximum similarity with Glycine max, 32.79\% with Cajanus cajan, $15.28 \%$ with Cicer arietinum, $15.06 \%$ with Glycine soja,11.86\% with
Phaseolus vulgaris, $10.53 \%$ with Medicago truncatula and remaining with other legume plants (Additional file 3: Figure S1). About $91.31 \%$ of the assembled unigenes had similarity of more than $60 \%$ at protein level with the existing proteins in NCBI database. The E-value distribution of $37.32 \%$ sequences ranged from $1 \mathrm{e}^{-50}$ to $1 \mathrm{e}^{-6}$ (Fig 1d). The similarity distribution analysis indicated that $59.74 \%$ sequences had similarity more than 80 and $40.26 \%$ sequences more than $40 \%$ with the sequences in NCBI (Fig 2a). Out of the total 102,479 unigenes, we could annotate and assign GO terms to 45,200 unigenes using the UniProt database (Fig 1c). The GO terms were distributed into 60 functional groups which were classified into three categories, namely, cellular components (2106), molecular functions (3889) and biological processes (3392). The top GO terms were ATP binding (2096), nucleus (1046), nucleic acid binding (1045), protein kinase activity (781), ADP binding (774), zinc ion binding (726), metal ion binding (717) and RNA binding (704) (Fig 3; Additional file 4: Table S3). A total of 7426 unigenes were grouped into six enzyme codes: Oxidoreductases (2207), Transferases (3907), Hydrolases (2527), Lyases (255), Isomerases (305) and Ligases (656) (Fig 2b). The most frequent terms among the unigenes annotated by KAAS were "metabolic pathways (905)", "biosynthesis of secondary metabolities (407)", "biosynthesis of antibiotics (211)", "microbial
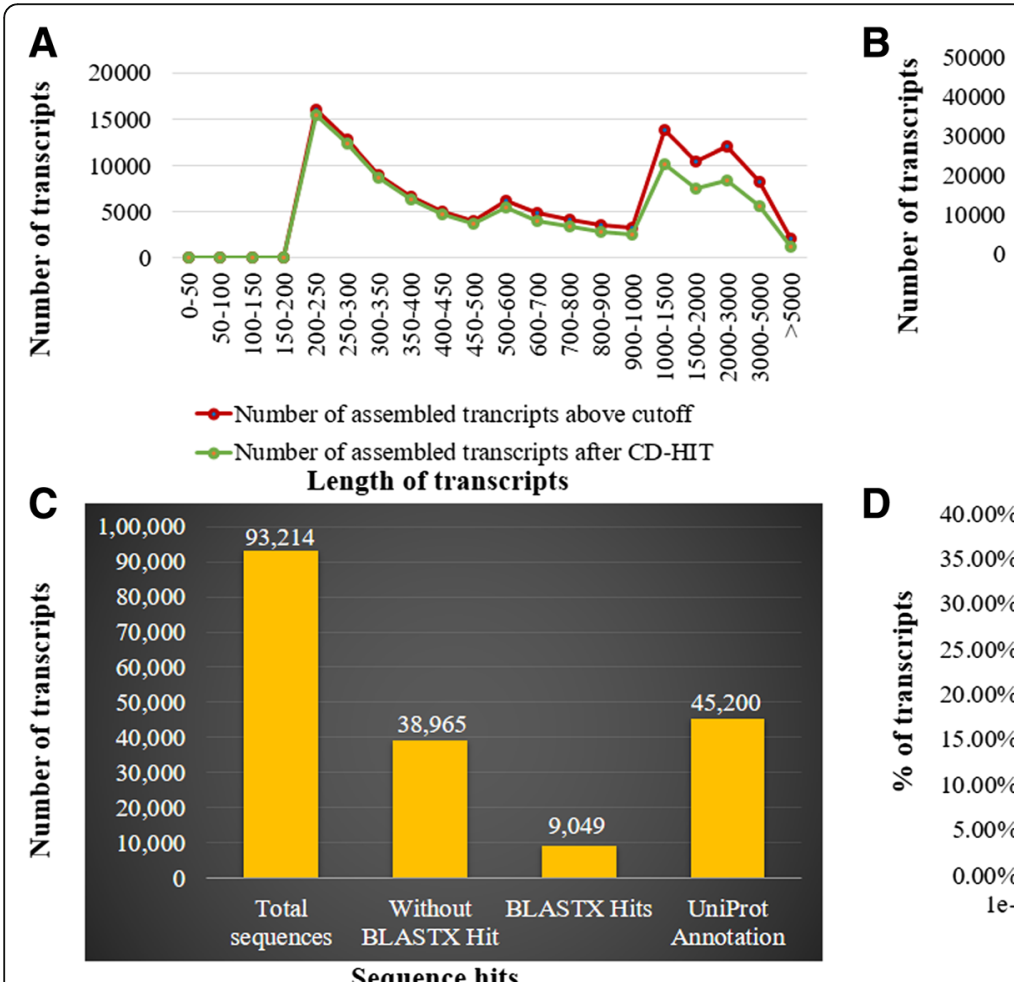

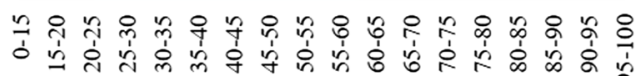

- Number of assembled transcripts before CD-HIT

- Number of assembled transcripts after CD-HIT GC Content

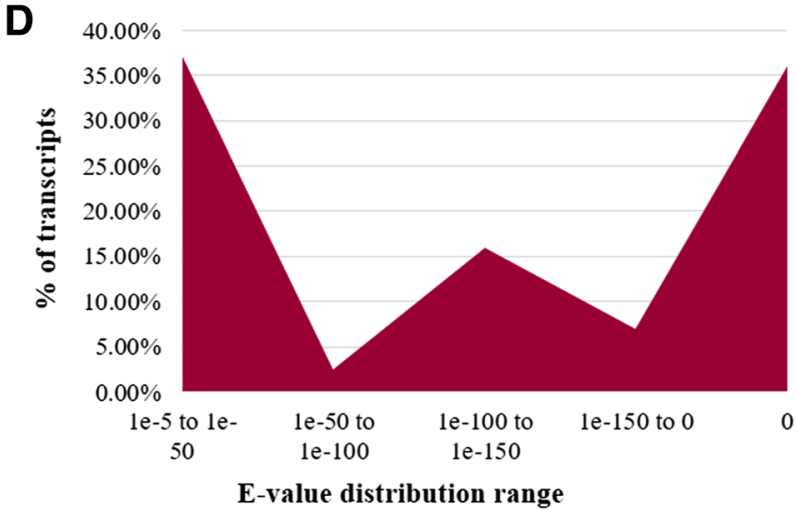

Fig. 1 Functional annotation of guar root transcriptome $\mathbf{a}$. Length distribution b. GC distribution c. Distribution of total sequences obtained from Blast2GO three step processes including BLASTX, mapping and annotation of guar root transcriptome $\mathbf{d}$. BLASTX E-value distribution 
Table 2 Statistics of de novo assembly of root transcriptome of guar

\begin{tabular}{ll}
\hline Characteristic & Details \\
\hline Total number of transcripts & 1,02479 \\
Min length & 201 \\
Max length & 16,844 \\
Average length & 1016.62 \\
Standard deviation & 1150.28 \\
Median length & 500 \\
Number of contigs $<500 \mathrm{bp}$ & 51,229 \\
Number of contigs $\geq 500 \mathrm{bp}$ & 51,250 \\
Number of contigs $\geq 1000 \mathrm{bp}$ & 32,949 \\
Number of contigs $\geq 2000 \mathrm{bp}$ & 15,360 \\
Number of contigs $\geq 5000 \mathrm{bp}$ & 1297 \\
N50 & 1907 \\
Contigs in N50 & 16,574 \\
GC content & $39.82 \%$ \\
\hline
\end{tabular}

metabolism in diverse environments (157)" and "ribosome (130)" (Additional file 5: Table S4).

\section{Identification and characterization of 18,792 SSR markers}

In order to reduce the bias of transcript length and noise at low level of expression, the unigenes having fragments per kilobase of transcript per million mapped reads (FPKM) $\geq 1$ were selected to identify simple sequence repeats (SSRs) [30]. A total of 18,792 simple sequence repeats (SSRs) belonging to 8 classes of microsatellites were identified in 93,402 unigenes having FPKM $\geq 1$. The characteristics of all the identified SSRs, namely, length of SSR, type of SSR, size of SSR and start and end positions of SSR, have been given in Additional file 6: Table S5. Out of the total 18,792 SSRs, 9983 (52.62\%) SSRs were mono-nucleotide, 3455 (18.21\%) di-nucleotide, 3914 (20.63\%) tri-nucleotide, 373 (1.97\%) tetra-nucleotide, $70(0.37 \%)$ penta-nucleotide, 58 (0.31\%) hexa-nucleotide, 1073 (5.7\%) c1 and 46 (0.25\%) c2 motifs. The 'c1' are compound motifs containing two types of repeats separated by few nucleotides and $\mathrm{c} 2$ are compound motifs in which two types of repeats are not separated by a

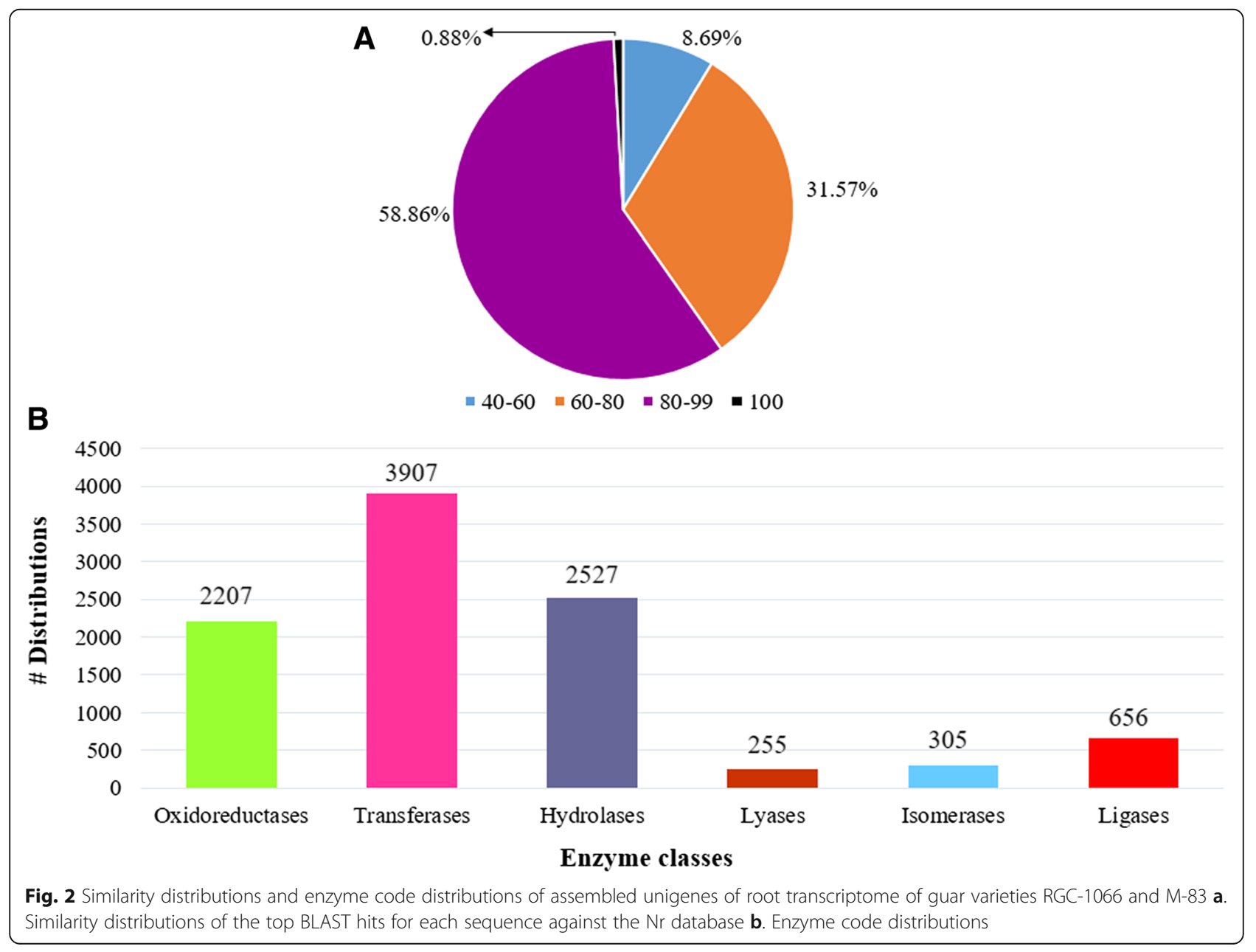




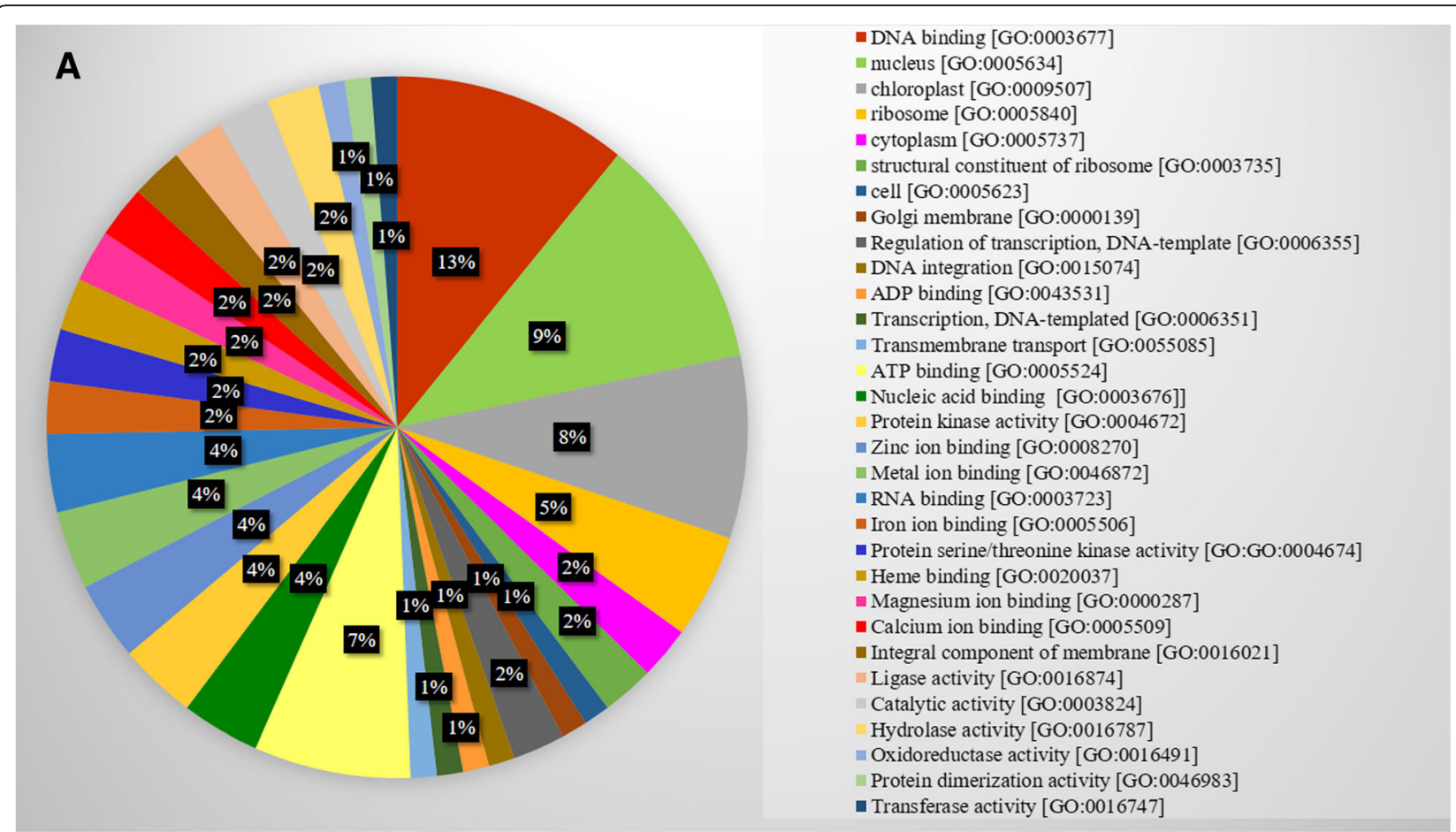

Fig. 3 Distribution of biological, molecular and cellular component categories in unigenes of guar root transcriptome

nucleotide stretch. For each identified SSR, an attempt was made to find the name and characteristics (function/protein product) of the gene containing the SSR. We succeeded in doing so for 12,600 SSRs. The detailed data for mono-, di-, tri-, tetra-, penta-, hexa-, c and $\mathrm{c}^{*}$ SSRs have been presented in Additional file 7: Table S6, Additional file 8: Table S7, Additional file 9: Table S8, Additional file 10: Table S9, Additional file 11: Table S10, Additional file 12: Table S11, Additional file 13: Table S12, Additional file 14: Table S13.

For 1732 dinucleotide SSRs, the repeat number varied from 6 to 9, while the repeat number for 2050 trinucleotides, 201 tetranucleotides, 67 pentanucleotides and 50 hexanucleotides were $\leq 5$ (Table 3). On an average, the unigenes contained $1 \mathrm{SSR}$ per $5.45 \mathrm{~kb}$. A total of 1073 (5.66\%) SSRs were repeated more than 10 times whereas $46(0.24 \%)$ SSRs were repeated more than 20 times. The most abundant class of repeat motifs were mononucleotides $(52.62 \%)$ followed by tri-nucleotides $(20.63 \%)$ and dinucleotides (18.21\%). The distribution frequencies and per cent distribution of SSRs have been given in Table 4 and Additional file 15: Table S14. The motifs AG, AGG, AAAG, AGAAAG, CT, TTC, CTTT, ATGAG and TGCTAT were more prevalent than the other motifs in the root transcriptome of guar (Additional file 7: Table S6, Additional file 8: Table S7, Additional file 9: Table S8, Additional file 10: Table S9, Additional file 11: Table S10, Additional file 12: Table S11, Additional file 13: Table S12, Additional file 14: Table S13). Out of 20 randomly chosen
SSRs, 15 showed amplification in both guar varieties, 3 in RGC-1066 variety and 2 in M-83 variety. The results of amplification of 7 SSRs in both guar varieties have been shown in Additional file 16: Figure S2A.

\section{SNPs identified and characterized}

A total of 27,446, 14,578 and 5999 single nucleotide polymorphisms (SNPs) were identified at read depths (RDs) of 2, 5 and 10, respectively, in the RGC-1066 and M-83 varieties of guar (Fig 4a, c). On an average, 1 SNP per $17.08 \mathrm{~kb}$ was found in the unigenes, at RD10. The SNPs obtained at higher RDs are considered to be high-confidence SNPs as compared to the ones obtained at lower RDs. Hence the SNPs obtained at the RD of 10 were used for further study. At this RD, the varieties RGC-1066 and M-83 were found to contain 2479 and 2870 SNPs, respectively (Additional file 17: Table S15). The SNP names, description/annotation of the SNP-containing unigenes, and alleles and positions of 4851 SNPs have been given in the Additional file 18: Table S16. These SNPs were found to be located in 2400 unigenes. The highest number of SNPs was found in the RNA dependent RNA polymerase (506) unigene. A total of 86 SNPs were found in 47 transcription factors which are involved in intracellular signaling, stress tolerance, regulation of cell cycle, cell growth, apoptosis and defense mechanisms. The LOC101508115 and Gag-Pol polyprotein unigenes, which are involved in nucleic acid binding and DNA integration, contained 58 and 49 SNPs, respectively. 
Table 3 Repeat numbers of different SSRs obtained from the guar root transcriptome

\begin{tabular}{|c|c|c|c|c|}
\hline \multirow[t]{2}{*}{ Repeat type } & \multicolumn{3}{|c|}{ Repeat numbers } & \multirow{2}{*}{$\begin{array}{l}\text { Total } \\
\text { number } \\
\text { of } \\
\text { repeats }\end{array}$} \\
\hline & $\leq 5$ & 6 to 9 & $\geq 10$ & \\
\hline Mononucleotides & - & - & 9983 & 9983 \\
\hline Dinucleotides & - & 1732 & 1723 & 3455 \\
\hline Trinucleotides & 2050 & 1334 & 530 & 3914 \\
\hline Tetranucleotides & 201 & 172 & - & 373 \\
\hline Pentanucleotides & 67 & 3 & - & 70 \\
\hline Hexanucleotides & 50 & 8 & - & 58 \\
\hline
\end{tabular}

The transition and transversion analysis of the SNPs has been presented in the Table 5. The total number of transition and transversion mutations were 3033 (62\%) and $1803(38 \%)$, respectively, with a $\mathrm{Ts} / \mathrm{Tv}$ ratio of 1.72 (Table 5). Among the transition mutations, $\mathrm{T} /$ $\mathrm{C}$ and $\mathrm{A} / \mathrm{G}$ showed high occurrences of 18.7 and $17.8 \%$, respectively. The $\mathrm{A} / \mathrm{T}$ and $\mathrm{T} / \mathrm{A}$ mutations had high occurrences of 6.1 and 5.6\%, respectively, among the transversion mutations. Five SNPs, namely, OT2,

Table 4 Percentage distribution frequencies of SSR motif repeats in guar root transcriptome

\begin{tabular}{|c|c|c|c|c|c|c|c|c|}
\hline \multirow{2}{*}{$\begin{array}{l}\text { Repeat } \\
\text { number }\end{array}$} & \multicolumn{8}{|c|}{ Repeat type } \\
\hline & Mono- & Di- & Tri- & Tetra- & Penta- & Hexa- & C & $c^{*}$ \\
\hline 1 & 0 & 0 & 0 & 0 & 0 & 0 & 0 & 0 \\
\hline 2 & 0 & 0.01 & 0 & 0 & 0 & 0 & 0 & 0 \\
\hline 3 & 0 & 0 & 0 & 0 & 0 & 0 & 0 & 0 \\
\hline 4 & 0 & 0 & 0 & 0 & 0 & 0 & 0 & 0 \\
\hline 5 & 0 & 0 & 11 & 1 & 0.3 & 0.2 & 0 & 0 \\
\hline 6 & 0 & 5 & 5 & 0.4 & 0.01 & 0.01 & 0 & 0 \\
\hline 7 & 0 & 3 & 2 & 0.1 & 0 & 0 & 2 & 0 \\
\hline 8 & 0 & 1 & 2 & 0.01 & 0 & 0 & 1 & 0 \\
\hline 9 & 0 & 1 & 1 & 0 & 0 & 0 & 0.1 & 0 \\
\hline 10 & 14 & 0.4 & 0.1 & 0 & 0 & 0 & 0 & 0 \\
\hline 11 & 7 & 0.4 & 0.4 & 0 & 0 & 0 & 0 & 0 \\
\hline 12 & 4 & 0.05 & 0.2 & 0 & 0 & 0 & 0 & 0 \\
\hline 13 & 3 & 0.05 & 0.1 & 0 & 0 & 0 & 0 & 0.1 \\
\hline 14 & 2 & 0.06 & 0.01 & 0 & 0 & 0 & 0 & 0.01 \\
\hline 15 & 2 & 0.03 & 0.1 & 0 & 0 & 0 & 0 & 0 \\
\hline 16 & 1 & 0.01 & 0.1 & 0 & 0 & 0 & 0 & 0 \\
\hline 17 & 1 & 0 & 0.01 & 0 & 0 & 0 & 0 & 0 \\
\hline 18 & 0.4 & 0.02 & 0 & 0 & 0 & 0 & 0 & 0 \\
\hline 19 & 0.2 & 0.01 & 0 & 0 & 0 & 0 & 0 & 0 \\
\hline 20 & 0.1 & 0 & 0 & 0 & 0 & 0 & 0 & 0 \\
\hline$\geq 20$ & 0.6 & 0 & 0 & 0 & 0 & 0 & 0 & 0 \\
\hline
\end{tabular}

OT3, OT105, OT243 and OT4846, randomly selected for validation showed PCR amplification (Additional file 16: Figure S2B).

Sixteen SNPs were found to be located in 6 unigenes associated with root development (Table 6; Additional file 19: Table S17; Fig 4d). These unigenes encode for cellulose synthase A and D5 like proteins which are involved in mannan synthesis, root hair morphogenesis and root cell wall biosynthesis. Nine transition and 7 transversion mutations were found in these six unigenes.

A total of 27 SNPs were found in 14 unigenes involved in defense responses, hypersensitive responses, negative regulation of $\mathrm{p} 53$, heat and cold stress responses (Table 7; Fig 4d; Additional file 20: Table S18). These unigenes, encoding for NB-LRR, NB-ARC, transcription factors, heat shock proteins, ring finger and zinc finger domain containing proteins, were found to contain 13 transition and 14 transversion mutations.

Fourteen SNPs were located in 7 unigenes involved in galactomannan synthesis (Table 8). Six SNPs were found in the KK1_009388 gene encoding cellulose synthase A catalytic subunit 1 involved in biosynthesis of mannan. These unigenes conatained 5 transitions and 9 transversions.

\section{Identification and characterization of 249 InDel markers}

A total of 720, 427 and 249 InDels (insertions+deletions) were recorded in the RGC-1066 and M-83 varieties of guar at RDs 2, 5 and 10, respectively (Fig 4b). Among the high-confidence 249 InDels, 160 (64.26\%) were insertions whereas 89 (35.74\%) were deletion mutations (Additional file 21: Table S19). Each of the two guar varieties was found to contain more insertions as compared to deletions. The main characteristics of 249 high-confidence InDels have been given in Additional file 19: Table S17. On an average, one insertion per $282.5 \mathrm{~kb}$ was found in the annotated unigenes. The high-confidence 160 insertions were found to be located in 153 unigenes. The average size of an insertion was $1.49 \mathrm{bp}$ with the range of 1-17 bp. The longest insertion of $17 \mathrm{bp}$ was found to be present in LOC101504041 gene involved in $\mathrm{N}$-acetyltransferase activity. On an average, one deletion was found per $507.9 \mathrm{~kb}$ in the annotated unigenes. These deletions were distributed in 87 unigenes. The average size of a deletion was $3.02 \mathrm{bp}$ with variations of 1-18 bp. The longest deletion of $18 \mathrm{bp}$ was located in the LOC100793810 GLYMA_07G170000 gene involved in tRNA methyltransferase activity and tRNA methylation.

\section{Differrential gene expression and metabolic network analyses}

Out of 404 unigenes (Benjamini-Hochberg adjusted $p$-value <0.05) differentially expressed by more than 


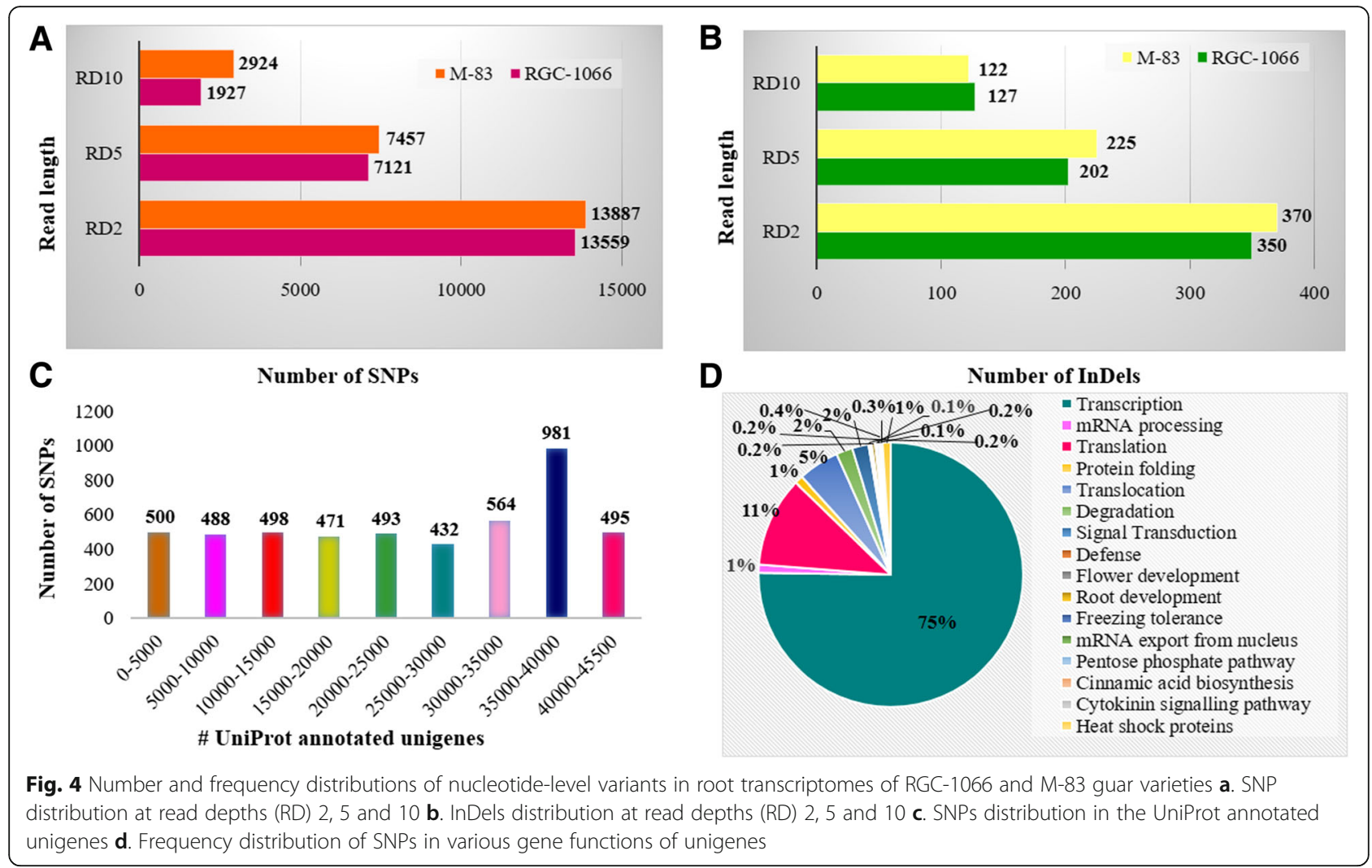

two-fold in the two studied varieties of guar, 227 and 177 unigenes were found to be upregulated in the RGC-1066 and M-83 varieties, respectively (Figs 5, 6; Additional file 22: Table S20, Additional file 23: Table S21). The Fig 6 shows the top 20\% of differentially expressed genes of RGC-1066 and M-83 varieties and the hierarchical distances of these genes. The detailed description of the differentially expressed genes has been presented in the Additional file 22: Table S20, Additional file 23: Table S21.

\section{Discussion}

Genetic improvement of the industrially important guar crop has been so far accomplished following the traditional plant breeding approaches without using molecular markers. A molecular plant breeding programme requires a rich resource of molecular markers which is lacking for the guar crop. As the genome of guar has not been sequenced yet, obtaining such markers is not easy.

Among the various molecular markers, SSRs, SNPs and InDels are considered to be very valuable. Recently, development of SSR [13, 15-17] and SNP [16] markers has been reported in guar. However, these markers are less in number in comparison to those available for the model crops, and do not cover all the expressed regions of guar genome. Further, these markers have not been well characterized. We report here the development and characterization of SSR, SNP and InDel markers for the guar crop by sequencing of the root transcriptome.

By de novo assembly and clustering of high quality sequence reads obtained from RNA-Seq of roots of two guar varieties, RGC-1066 and M-83 having contrasting phenotypic characters, we generated 102,479 unigenes. From the RNA-Seq of leaf tissues of these two varieties, Tanwar et al. [16] reported the generation of 62,146 unigenes. Rawal et al. [17] obtained 127,706 unigenes from the RNA-Seq of three tissues, namely, leaves, shoots and flowers of guar variety RGC936. The comparisons of our sequence data with those of the above two reports indicates that the unigenes obtained by us have a good coverage of guar root transcriptome which is a prerequite for obtaining sufficient number of genic markers covering most of the genes. The CEGMA analysis showed that the unigenes obtained had $86.55 \%$ complete and $97.71 \%$ partial CEGs, indicating that our collection of unigenes was suitable for obtaining a sufficient number of molecular markers for a wide variety of guar genes expressing in roots [31-33]. Similar results have been obtained in the leaf transcriptomic analysis of guar [16]. Rawal et al. [17] have, however, reported more completedness in their transcriptomic library derived from the flower, leaf and shoot tissues of guar. 
Table 5 Transition vs transversion mutation rate, type and ratio determined from the transcriptomes of RGC-1066 and M-83 varieties of guar

\begin{tabular}{|c|c|c|}
\hline $\begin{array}{l}\text { Transition type } \\
\text { A/G }\end{array}$ & $\begin{array}{l}\text { Occurance/Number } \\
865\end{array}$ & $\begin{array}{l}\text { Percent occurance (\%) } \\
17.8\end{array}$ \\
\hline $\mathrm{C} / \mathrm{T}$ & 585 & 12.04 \\
\hline $\mathrm{G} / \mathrm{A}$ & 673 & 13.9 \\
\hline $\mathrm{T} / \mathrm{C}$ & 910 & 18.7 \\
\hline Transversion type & Occurance/Number ${ }^{a}$ & Percent occurance (\%) \\
\hline $\mathrm{A} / \mathrm{C}$ & 206 & 4.2 \\
\hline$A / T$ & 297 & 6.1 \\
\hline$C / G$ & 202 & 4.1 \\
\hline $\mathrm{G} / \mathrm{T}$ & 214 & 4.4 \\
\hline$C / A$ & 232 & 4.8 \\
\hline T/A & 275 & 5.6 \\
\hline $\mathrm{G} / \mathrm{C}$ & 140 & 2.9 \\
\hline $\mathrm{T} / \mathrm{G}$ & 237 & 4.9 \\
\hline
\end{tabular}

${ }^{\mathrm{a} O u t}$ of 4907 SNPs

As the guar genome has not been sequenced, sequence similarity search of the 102,479 assembled unigenes was carried out by using BLASTX against six databases. A total of 54,249 unigenes had at least one significant match in blast hit results with E-value $<10^{-6}$ showing that these unigenes are protein coding. The main reason for not getting hits for the remaining unigenes is that very low amounts of genomic data is available for guar in the known databases. These unigenes appear to be guar specific and may be useful for further research to obtain novel gene products, introduce new traits in other organisms and understand some biological mechanisms at the molecular level. The highest similarity (45.65\%) of the assembled unigenes was found with G. max genes. Tanwar et al. [16] also reported $41.91 \%$ similarity of the guar unigenes with the genes of G. max. The leaf and root transcriptomic analyses of guar shows that G. $\max$ may be used as a suitable reference species for guar genetic analysis.

By screening of 102,479 unigenes assembled from the RNA-Seq data of two guar varieties, we obtained 25,040 high-confidence molecular markers which consist of 18,792 SSRs, 5999 SNPs and 249 InDels. The validation of random samples of these markers indicated that PCR amplification of most of these markers would be possible. The molecular markers identified by us have tagged most of the genes involved in root development, stress tolerance and other general metabolic activities. Each molecular marker has been characterized, particularly with respect to its precise position in the unigene containing it. For about $70 \%$ of the markers, we have been able to determine the characteristics of the genes containing these markers. We hope that the high-confidence molecular markers obtained by us, along with the others previously reported, will be helpful in studying molecular mechanisms of root development, stress tolerance and gum synthesis in guar. These markers are expected to contribute significantly to the breeding programmes based on marker-assisted selection, to develop improved varieties of guar.

Although we have enriched the guar molecular markers resource, this resource is still less than those available for the well-studied legume crops like soybean, Lotus, Medicago, pigeonpea and chickpea. Further research work, similar to ours, is needed to analyze the RNA-Seq data of other tissues of guar to obtain more molecular markers. The newly discovered molecular markers have to be characterized thoroughly. Genotyping-by-sequencing (GBS) would be better for a segregating population to obtain a high-density linkage map. The availability of the complete genomic sequence of guar will be highly helpful for the genetic improvement of this important crop.

\section{Conclusions}

A total of 102,479 unigenes were assembled from the RNA-Seq data of two guar varieties, namely, RGC-1066 and M-83. The screening of these unigenes resulted in the identification of 25,040 high-confidence molecular markers which consisted of 18,792 SSRs, 5999 SNPs and 249 InDels. These molecular markers have been found to tag most of the genes involved in root development, stress tolerance and other general metabolic activities. All the molecular markers have been characterized, particularly with respect to their positions in the unigenes. We could determine the names, products and functions of the unigenes for $71 \%$ of the molecular markers.

\section{Methods}

Plant material and growth conditions

The seeds of RGC-1066 and M-83 varieties of guar were obtained from Rajasthan Agricultural Research Institute, Durgapura, Jaipur (India). The RGC-1066 is a commercial gum-producing variety having hairy leaf surface and purple colour flowers. The beans of the M-83 variety are used as a vegetable. This variety has glabrous leaves and white flowers. The plants were grown under field conditions at Indian Institute of Technology Roorkee. The root samples of each variety were collected on the 25th day of seed sowing and sent to SciGenome Labs Pvt. Ltd., Cochin (India) for RNA-Seq.

\section{Transcriptome sequencing}

Three independent biological and technical replicates were used for cDNA library preparation and sequencing. The total RNA was extracted from the roots of each guar variety using Ambion ${ }^{\mathrm{R}}$ Plant RNA isolation kit and 
Table 6 Characteristics of the SNPs located in genes involved in root development of guar

\begin{tabular}{|c|c|c|c|c|c|c|}
\hline S. No. & SNP name & Gene name & SNP Allele & Position & Gene description & Gene function \\
\hline 1 & OT3537 & $\begin{array}{l}\text { KK1_009388/ LOC100798193 } \\
\text { GLYMA_06G069600 }\end{array}$ & $\mathrm{G} / \mathrm{T}$ & 594 & $\begin{array}{l}\text { cellulose synthase A catalytic } \\
\text { subunit } 1 \text { [UDP-forming] }\end{array}$ & $\begin{array}{l}\text { Transportation of mannose, } \\
\text { nucleotide-sugar transport }\end{array}$ \\
\hline 2 & OT2789 & -do- & C/A & 898 & -do- & $\beta(1,4)$ Mannan synthesis \\
\hline 3 & ОТ2790 & -do- & C/A & 899 & - do- & -do- \\
\hline 4 & OT2791 & -do- & $\mathrm{T} / \mathrm{C}$ & 917 & -do- & -do- \\
\hline 5 & OT2792 & - do- & $A / G$ & 959 & - do- & - do- \\
\hline 6 & ОT2793 & -do- & T/C & 960 & -do- & - do- \\
\hline 7 & ОT2794 & - do- & $\mathrm{G} / \mathrm{T}$ & 1322 & -do- & -do- \\
\hline 8 & OT4846 & $\begin{array}{l}\text { LOC100797597 } \\
\text { GLYMA_03G217500 }\end{array}$ & T/A & 344 & cellulose synthase-like protein D5 & -do- \\
\hline 9 & OT1382 & LR48_Vigan02g201500 & T/A & 901 & $\begin{array}{l}\text { cellulose synthase A catalytic } \\
\text { subunit } 2 \text { [UDP-forming]-like }\end{array}$ & -do- \\
\hline 10 & ОТ3553 & $\begin{array}{l}\text { LOC100789704 } \\
\text { GLYMA_12G002500 }\end{array}$ & $\mathrm{A} / \mathrm{C}$ & 1528 & $\begin{array}{l}\text { receptor-like protein kinase } \\
\text { HSL1-like isoform X1 }\end{array}$ & Regulation of root development \\
\hline 11 & OT3554 & -do- & $\mathrm{A} / \mathrm{G}$ & 3027 & -do- & -do- \\
\hline 12 & ОТ3555 & -do- & $A / G$ & 3037 & -do- & - do- \\
\hline 13 & OT3861 & $\begin{array}{l}\text { LOC100780184 } \\
\text { GLYMA_08G111400 }\end{array}$ & $A / G$ & 2864 & $\begin{array}{l}\text { uncharacterized protein } \\
\text { LOC100780184 }\end{array}$ & Root cell wall biosynthesis \\
\hline 14 & OT3862 & -do- & $A / G$ & 5661 & - do- & -do- \\
\hline 15 & OT3863 & -do- & $A / G$ & 7007 & -do- & -do- \\
\hline 16 & OT4656 & $\begin{array}{l}\text { LOC100795671 } \\
\text { GLYMA_12G192000 }\end{array}$ & $\mathrm{T} / \mathrm{C}$ & 2145 & $\begin{array}{l}\text { cellulose synthase-like protein } \\
\text { B3-like }\end{array}$ & Root hair morphogenesis \\
\hline
\end{tabular}

cDNA library was prepared using TruSeq Stranded Total RNA Sample Prep Guide. The sequencing of cDNA library was carried out on Illumina HiSeq 2500 machine to obtain the raw reads. As per the sequencing strategy of the machine, the average read length was $100 \mathrm{bp}$.

\section{De novo assembly, clustering and functional annotation} The adaptor and repetitive sequences from raw reads were removed by Trimmomatic, NGS-pipe and Fast QC v0.11.5 softwares [34] to generate clean reads. The clean reads from three independent biological replicates of each variety were assembled into a fastafile by using the Trinity program. The reads in a fastafile are known as unigenes. The clustering and quality checking of unigenes were done using CD-HIT v4.6.6 [35] and CEGMA (Core Eukaryotic Gene Mapping Approach) [16]. Functional annotation of guar root transcriptome was done using BLASTX tool of BLAST2GO suite. Homologs of assembled unigenes were searched in NCBI, UniProt, Pathway, Nt, Pfam and Uniref90 databases with default parameters. The BLAST + results were used to retrieve Gene Ontology (GO), and enzyme code (EC) terms using BLAST2GO suite. The functional and comparative analysis of othe assembled unigenes was done using TRAPID tool [36] to find closely related species. To understand the molecular datasets obtained at biological and functional level, the assembled unigenes were further annotated with KAAS (KEGG Automatic Annotation Server: http://www.genome..jp/kegg/kaas/) [37].

\section{Mining, validation and in silico analysis of SSRs}

The mining of mono-, di-, tri-, tetra-, penta-, hexa-, and compound SSR markers was done using MISA tool, followed by validation and in silico analysis as given in [16]. Twenty SSR markers were randomly selected for validation. The primers were designed for these markers using Primer3 tool [38]. PCR with the above primers was carried out on the DNA samples extracted from the roots of RGC-1066 and M-83 guar varieties using DNeasy Plant Mini Kit (QIAGEN). The amplified PCR products were visualized on $3 \%$ agarose gel.

\section{Identification of single nucleotide polymorphisms (SNPs) and insertions and deletions (InDels)}

The high quality clean transcriptomic sequence reads of two guar varieties RGC-1066 and M-83 were mapped on to the assembled unigenes using Bowtie2 version 2.3.2 software [39] (http://bowtie-bio.sourceforge.net/index.shtml) to obtain BAM files. These files were used to identify each read that mapped to only one position of the reference genome (de novo assembly). The FastQC version 0.11 .5 tool (http://www.bioinformatics.babraham.ac.uk/projects/ fastqc/) was used for base quality filtration. The identification of SNPs and InDels was done using SAMtools version 
Table 7 Characteristics of SNPs located in guar unigenes involved in biotic and abiotic stress responses

\begin{tabular}{|c|c|c|c|c|c|c|}
\hline S. No. & SNP name & Gene name & SNP allele & SNP position & Gene description & Gene function \\
\hline 1 & OT769 & MTR_2g078070 & $A / G$ & 3008 & NBS-LRR type & Defense response \\
\hline 2 & OT1113 & KK1_009739 & $\mathrm{G} / \mathrm{T}$ & 272 & $\begin{array}{l}\text { Disease resistance } \\
\text { protein } \mathrm{RGA2}\end{array}$ & $\begin{array}{l}\text { Late blight } \\
\text { (Phytophthora infestans) } \\
\text { resistance }\end{array}$ \\
\hline 3 & OT1114 & -do- & $A / G$ & 428 & -do- & -do- \\
\hline 4 & OT1115 & -do- & $A / G$ & 485 & - do- & -do- \\
\hline 5 & OT1116 & -do- & $\mathrm{A} / \mathrm{C}$ & 1845 & -do- & -do- \\
\hline 6 & OT1161 & MTR_3g035960 & $\mathrm{A} / \mathrm{T}$ & 978 & $\begin{array}{l}\text { NBS-LRR type disease } \\
\text { resistance protein }\end{array}$ & $\begin{array}{l}\text { R (Resistance) genes, } \\
\text { plant defense }\end{array}$ \\
\hline 7 & OT1162 & -do- & $\mathrm{T} / \mathrm{C}$ & 1196 & - do- & - do- \\
\hline 8 & OT1163 & - do- & $A / G$ & 2357 & - do- & -do- \\
\hline 9 & OT1431 & KK1_033834 & $\mathrm{C} / \mathrm{T}$ & 493 & $\begin{array}{l}\text { Disease resistance } \\
\text { RPP13-like protein } 1\end{array}$ & $\begin{array}{l}\text { Plant hypersensitive response, } \\
\text { disease resistance }\end{array}$ \\
\hline 10 & OT1432 & -do- & $A / G$ & 528 & -do- & -do- \\
\hline 11 & OT1433 & -do- & T/G & 548 & -do- & -do- \\
\hline 12 & OT1434 & - do- & C/A & 549 & - do- & - do- \\
\hline 13 & OT1435 & -do- & $\mathrm{T} / \mathrm{G}$ & 550 & - do- & -do- \\
\hline 14 & OT1436 & - do- & T/A & 593 & - do- & - do- \\
\hline 15 & OT1437 & -do- & $\mathrm{G} / \mathrm{A}$ & 1323 & -do- & -do- \\
\hline 16 & OT1881 & MTR_3g466750 & $C / G$ & 1389 & $\begin{array}{l}\text { NB-ARC domain disease } \\
\text { resistance protein }\end{array}$ & Defense response \\
\hline 17 & OT1916 & MTR_3g020890 & $\mathrm{A} / \mathrm{G}$ & 290 & $\begin{array}{l}\text { NB-LRR type disease resistance } \\
\text { protein Rps1-k-2 }\end{array}$ & Phytophthora resistance \\
\hline 18 & OT2923 & KK1_021617 & & 588 & S-norcoclaurine synthase & $\begin{array}{l}\text { Pathogen related (PR) } 10 \\
\text { protein, defense response }\end{array}$ \\
\hline 19 & OT2924 & - do- & $\mathrm{C} / \mathrm{G}$ & 648 & -do- & - do- \\
\hline 20 & OT3720 & MTR_2g020040 & $\mathrm{G} / \mathrm{A}$ & 876 & $\begin{array}{l}\text { RING finger and } \mathrm{CHY} \text { zinc finger } \\
\text { domain-containing protein }\end{array}$ & Negative regulation of p53 \\
\hline 21 & OT67 & KK1_005680 & $C / T$ & 228 & KK1_005680 & Response to freezing \\
\hline 22 & OT458 & TCM_044345 & $\mathrm{G} / \mathrm{A}$ & 2522 & dnaJ protein homolog & Response to heat stress \\
\hline 23 & OT543 & KK1_034657 & T/A & 718 & Heat shock factor protein HSF24 & Response to heat stress \\
\hline 24 & OT3934 & $\begin{array}{l}\text { LOC100818430 } \\
\text { GLYMA_13G105700 }\end{array}$ & $A / T$ & 218 & $\begin{array}{l}\text { heat stress transcription factor } \\
\text { A-2-like }\end{array}$ & Response to heat stress \\
\hline 25 & ОТ3935 & - do- & $\mathrm{G} / \mathrm{T}$ & 590 & - do- & - do- \\
\hline 26 & OT1691 & KK1_001069 & $A / T$ & 79 & $\begin{array}{l}\text { Heat stress transcription factor } \\
\text { A-5 }\end{array}$ & Response to heat stress \\
\hline 27 & OT1738 & $\begin{array}{l}\text { LOC100820566 } \\
\text { GLYMA_13G225700 }\end{array}$ & $C / T$ & 146 & $\begin{array}{l}\text { Heat stress transcription factor } \\
\text { A-4a-like }\end{array}$ & Response to heat stress \\
\hline
\end{tabular}

1.4 software [40], by setting default parameters at read depths 2, 5 and 10. The SNPs and InDels obtained were manually characterized.

\section{Validation of SNPs by AS-PCR (allele-specific PCR)}

Allele specific PCR [41] was performed for the validation of SNPs. The DNA was extracted by CTAB method from the root of a 25 day old guar plant. Three primers, namely, forward, reverse and allele specific, were designed for amplification of each gene. The PCR amplification was performed using Applied Biosystem
Veriti 96-well thermal cycler in a $20 \mu \mathrm{l}$ reaction volume containing $150 \mathrm{ng}$ of genomic DNA, 1X Taq buffer, $2 \mathrm{mM} \mathrm{MgCl}, 0.2 \mathrm{mM}$ dNTP, $0.5 \mathrm{mM}$ primers and 1 unit of Taq Polymerase. The gene sequences were amplified from genomic DNA of each guar variety at initial denaturation of $94{ }^{\circ} \mathrm{C}$ for 5 mins, 30 cycles of denaturation at $94{ }^{\circ} \mathrm{C}$ for $30 \mathrm{~s}$, annealing at $60{ }^{\circ} \mathrm{C}$ for $45 \mathrm{~s}$, extension at $72{ }^{\circ} \mathrm{C}$ for $60 \mathrm{~s}$ and final extension of $10 \mathrm{~min}$ at $72{ }^{\circ} \mathrm{C}$. The amplified PCR products were visualized on $1.5 \%$ agarose gel and documented on gel documentation unit (Bio-Rad). 
Table 8 Characteristics of the SNPs located in genes involved in galactomannan synthesis in guar

\begin{tabular}{|c|c|c|c|c|c|c|c|}
\hline S. No. & SNP name & SNP allele & Type of SNP & Position & Gene name & Gene description & Function \\
\hline 1 & OT697 & T/A & TV & 1856 & LOC106775241 & $\begin{array}{l}\text { PREDICTED: callose synthase } \\
\text { 11-like [Vignaradiata var. radiata] }\end{array}$ & $\begin{array}{l}\text { Control delivery of } \\
\text { UDP-Glc to the synthase }\end{array}$ \\
\hline 2 & OT698 & $A / G$ & $\pi$ & 4865 & -do- & -do- & - do- \\
\hline 3 & OT1715 & $C / G$ & TV & 5925 & glysoja_027079 & Callose synthase 3 [Glycine soja] & -do- \\
\hline 4 & OT4075 & $A / T$ & TV & 2011 & KK1_031323 & Callose synthase 3 [Cajanuscajan] & -do- \\
\hline 5 & OT4076 & $C / G$ & TV & 3624 & -do- & -do- & -do- \\
\hline 6 & OT4342 & $\mathrm{T} / \mathrm{C}$ & $\pi$ & 6780 & $\begin{array}{l}\text { LOC100787540 } \\
\text { GLYMA_10G295100 }\end{array}$ & $\begin{array}{l}\text { PREDICTED: callose synthase } \\
\text { 9-like isoform } 1 \text { [Glycine max] }\end{array}$ & -do- \\
\hline 7 & OT1366 & T/A & TV & 901 & LR48_Vigan02g201500 & $\begin{array}{l}\text { PREDICTED: cellulose synthase } \\
\text { A catalytic subunit } 2 \\
\text { [UDP-forming]-like [Vignaangularis] }\end{array}$ & -do- \\
\hline 8 & OT2742 & C/A & TV & 898 & KK1_009388 & $\begin{array}{l}\text { Cellulose synthase A catalytic } \\
\text { subunit } 1 \text { [UDP-forming] } \\
\text { [Cajanuscajan] }\end{array}$ & Mannan biosynthesis \\
\hline 9 & OT2743 & C/A & TV & 899 & -do- & -do- & -do- \\
\hline 10 & OT2744 & $\mathrm{T} / \mathrm{C}$ & $\pi$ & 917 & -do- & -do- & -do- \\
\hline 11 & OT2745 & $A / G$ & $\pi$ & 959 & -do- & -do- & -do- \\
\hline 12 & OT2746 & $\mathrm{T} / \mathrm{C}$ & $\pi$ & 960 & -do- & -do- & -do- \\
\hline 13 & OT2747 & $\mathrm{G} / \mathrm{T}$ & TV & 1322 & -do- & -do- & -do- \\
\hline 14 & ОТ3490 & $\mathrm{G} / \mathrm{T}$ & TV & 594 & $\begin{array}{l}\text { LOC100798193 } \\
\text { GLYMA_06G069600 }\end{array}$ & $\begin{array}{l}\text { hypothetical protein } \\
\text { GLYMA_06G069600 } \\
\text { [Glycine max] }\end{array}$ & -do- \\
\hline
\end{tabular}
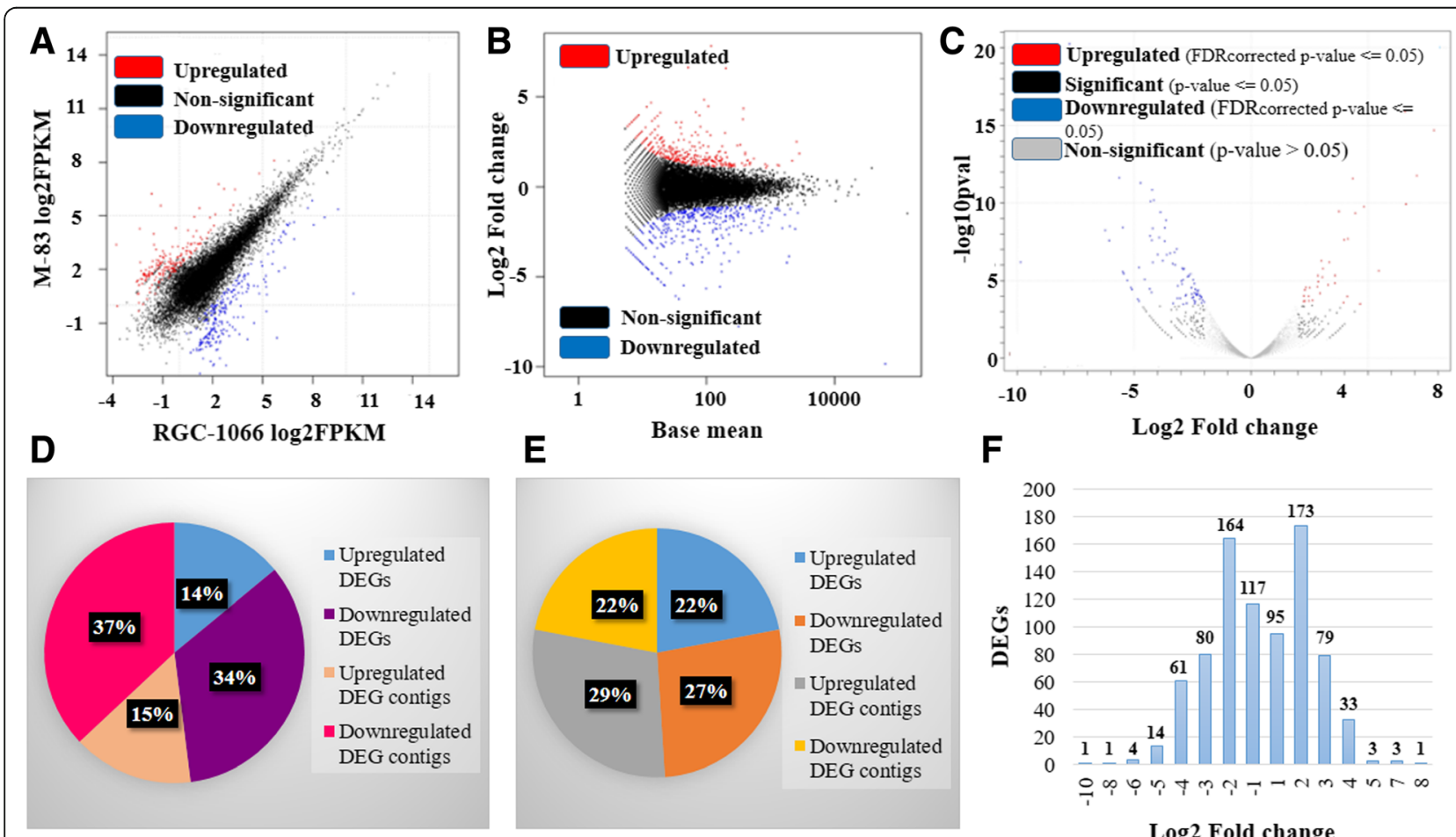

$\mathbf{F}$

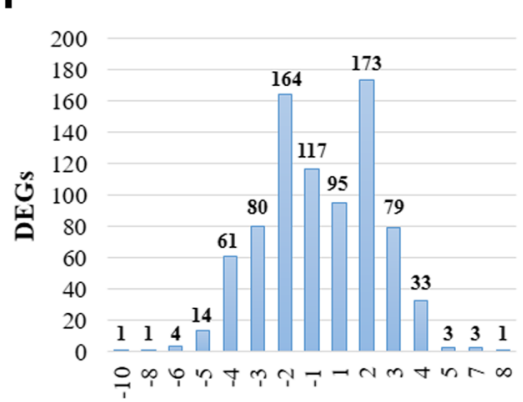

\section{Log2 Fold change}

Fig. 5 Distribution of differentially expressed genes in the roots of RGC-1066 and M-83 varieties of guar (a) FPKM plot (b) MA plot (log2Fold change vs Base mean) (c) Volcano plot (-log10pval vs log2Foldchange) (d) Pie padj plot (e) Pie pval plot (f) Bar plot of log2foldchange of upregulated, downregulated and non-significant unigenes 


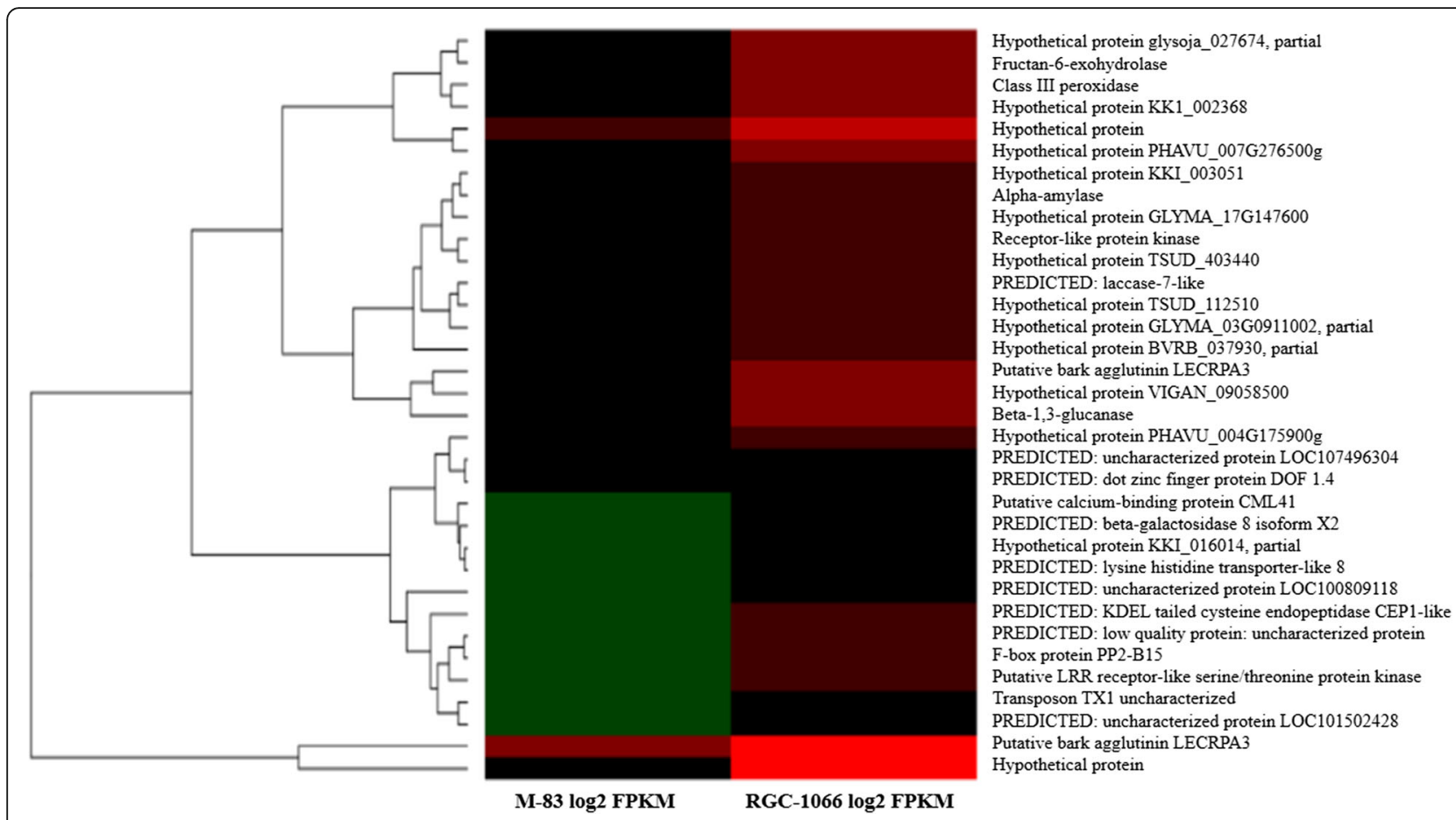

Fig. 6 Heat-map representation of highly upregulated and downregulated differentially expressed genes in the roots of RGC-1066 and M-83 varieties of guar

\section{Identification of differentially expressed genes}

The differential gene expression and metabolic network analyses of unigenes of RGC-1066 and M-83 varieties of guar were performed using DeSeq2 program (http:// www.bioconductor.org/packages/release/bioc/html/DESeq2. html) [42] and plant metabolic network database (http:// www.plantcyc.org).

\section{Additional files}

Additional file 1: Table S1. Number of transcripts and GC \% of transcripts generated after de novo assembly of clean reads. (DOCX $11 \mathrm{~kb}$ )

Additional file 2: Table S2. Statistics of CEGMA results of guar root transcriptome assembly. (DOCX $12 \mathrm{~kb}$ )

Additional file 3: Figure S1. BLASTX distribution of unigenes obtained from root transcriptome of guar in different plant species. (TIF $410 \mathrm{~kb}$ )

Additional file 4: Table S3. Distribution classification of gene ontology (GO) terms in 45200 guar root unigenes. (XLSX 184 kb)

Additional file 5: Table S4. Pathway mapping of annotated unigenes of RGC-1066 and M-83 varieties of guar using KAAS-KEGG automatic annotation server. (DOCX $51 \mathrm{~kb}$ )

Additional file 6: Table S5. List of characteristics of 18972 SSR markers obtained from root transcriptome of guar. (XLS $2191 \mathrm{~kb}$ )

Additional file 7: Table S6. Characteristics of mononucleotide SSRs obtained in RGC-1066 and M-83 varieties of guar. (XLSX $391 \mathrm{~kb}$ )

Additional file 8: Table S7. Characteristics of dinucleotide SSRs obtained in RGC-1066 and M-83 varieties of guar. (XLSX $142 \mathrm{~kb}$ )

Additional file 9: Table S8. Characteristics of trinucleotide SSRs obtained in RGC-1066 and M-83 varieties of guar. (XLSX $177 \mathrm{~kb}$ )
Additional file 10: Table S9. Characteristics of tetranucleotide SSRS obtained in RGC-1066 and M-83 varieties of guar. (XLSX $22 \mathrm{~kb}$ )

Additional file 11: Table S10. Characteristics of pentanucleotide SSRs obtained in RGC-1066 and M-83 varieties of guar. (XLSX $11 \mathrm{~kb}$ )

Additional file 12: Table S11. Characteristics of hexanucleotide SSRs obtained in RGC-1066 and M-83 varieties of guar. (XLSX $12 \mathrm{~kb}$ )

Additional file 13: Table S12. Characteristics of compound SSRS obtained in RGC-1066 and M-83 varieties of guar. (XLSX $60 \mathrm{~kb}$ )

Additional file 14: Table S13. Characteristics of compound* SSRs obtained in RGC-1066 and M-83 varieties of guar. (XLSX $10 \mathrm{~kb}$ )

Additional file 15: Table S14. Frequency distribution of identified SSR repeats in RGC-1066 and M-83 guar varieties. (XLSX 13 kb)

Additional file 16: Figure S2A. PCR amplification results of SSR markers. Fig S2B. PCR amplification results of SNP markers. (TIF $1146 \mathrm{~kb}$ )

Additional file 17: Table S15. List of SNPS in RGC-1066 and M-83 guar varieties. (XLSX 2293 kb)

Additional file 18: Table S16. Characteristics of SNPs obtained at RD10 from root transcriptome of guar varieties RGC-1066 and M-83. (XLSX 356 kb)

Additional file 19: Table S17. List of the primers used to study the SNPs present in root development genes of guar. (DOCX $12 \mathrm{~kb}$ )

Additional file 20: Table S18. List of the primers used to study the SNPs located in guar unigenes involved in biotic and abiotic stress responses. (DOCX $13 \mathrm{~kb}$ )

Additional file 21: Table S19. Characteristics of InDels obtained at RD10 from root transcriptome of guar varieties RGC-1066 and M-83. (XLSX $37 \mathrm{~kb}$ )

Additional file 22: Table S20. Detailed description of differentially expressed genes of RGC-1066 variety of guar. (XLS $443 \mathrm{~kb}$ )

Additional file 23: Table S21. Detailed description of differentially expressed genes of M-83 variety of guar. (XLS 442 kb) 


\section{Abbreviations}

AS-PCR: Allele-specific PCR; CEGMA: Core eukaryotic gene mapping approach: CEGs: Conserved eukaryotic genes; EC: Enzyme code; GO: Gene ontology; InDel: Insertion-deletion; ISSR: Inter simple sequence repeat; NSG: Next generation sequencing; PCR: Polymerase chain reaction; RAPD: Random amplified polymorphic DNA; rDNA: Ribosomal DNA; RNA-Seq: Ribonucleic acid sequence; SCAR: Sequence characterized amplified region; SNP: Single nucleotide polymorphism; SSR: Simple sequence repeat

\section{Acknowledgements}

We would like to thank Prof. Sudesh Kumar, RARl, Jaipur for providing the seed material and Dr. Umesh Kumar Tanwar, Warsaw, Poland for useful suggestions. Financial support for this work in the form of Assistantship to Omika Thakur by the Ministry of Human Resource Development, Govt. of India, is gratefully acknowledged. We are thankful to Dr. Ravinder Singh and Dr. Ankita Gurao for their kind help in proofreading.

\section{Funding}

This work was not supported by any research grant. Assistantship was provided to OT for carrying out this work.

\section{Availability of data and materials}

The RNA-Seq data has been uploaded on the NCBI website (SRA accession: PRJNA497670Temporary Submission ID: SUB4659462). All other data analyzed during this study are included in this article and its supplementary information files.

\section{Authors' contributions}

OT planned the experiments, did the experimental work, analyzed the data and wrote the paper. GSR planned the experiments, interpreted the results and corrected the manuscript. Both authors read and approved the final manuscript.

\section{Ethics approval and consent to participate}

Not applicable.

\section{Consent for publication}

Not applicable.

\section{Competing interests}

The authors declare that they have no competing interests.

\section{Publisher's Note}

Springer Nature remains neutral with regard to jurisdictional claims in published maps and institutional affiliations.

\section{Received: 27 February 2018 Accepted: 28 October 2018}

\section{Published online: 20 December 2018}

\section{References}

1. Dhugga KS, Barreiro R, Whitten B, Stecca K, Hazebroek J, Randhawa GS, et al. Guar seed beta-mannan synthase is a member of the cellulose synthase super gene family. Science. 2004;303:363-6.

2. Dwivedi NK, Bhandari DC, Dubas BS, Agrawal RC, Mandal S, Rana RS. Catalogue on cluster bean (Cyamopsis tetragonoloba (L.) Taub ) germplasm part III. New Delhi: NBPGR; 1995.

3. Yadav H, Prasad AK, Goswami P, Pednekar S, Haque E, Shah M. Guar industry Outlook 2015. Report made for: National Commodity \& Derivatives Exchange Limited. November 2013 ed. Jaipur: NIAM; 2013.

4. Slavin JL, Greenberg NA. Partially hydrolyzed guar gum: clinical nutrition uses. Nutrition. 2003;19:549-52

5. Giannini EG, Mansi C, Dulbecco P. Savarino V. Role of partially hydrolyzed guar gum in the treatment of irritable bowel syndrome. Nutrition. 2006;22: 334-42.

6. Butt MS, Shahzadi N, Sharif MK, Nasir M. Guar gum: a miracle therapy for hypercholesterolemia, hyperglycemia and obesity. Crit Rev Food Sci Nutr. 2007;47:389-96.

7. Morgante M, Hanafey M, Powell W. Microsatellites are preferentially associated with nonrepetitive DNA in plant genomes. Nat Genet. 2002;30: 194-200.
8. Kesawat MS, Kumar BD. Molecular markers: It's application in crop improvement. J Crop Sci Biotechnol. 2009;12:169-81.

9. Punia A, Yadav R, Arora P, Chaudhury A. Molecular and morphophysiological characterization of superior cluster bean (Cymopsis tetragonoloba) varieties. J Crop Sci Biotechnol. 2009;12:143-8.

10. Pathak R, Singh SK, Singh M, Henry A. Molecular assessment of genetic diversity in cluster bean (Cyamopsis tetragonoloba) genotypes. J Genet. 2010;89:243-6.

11. Pathak R, Singh SK, Singh M. Assessment of genetic diversity in clusterbean based on nuclear rDNA and RAPD markers. J Food Legumes. 2011;24:180-3.

12. Kuravadi NA, Tiwari PB, Choudhary M, Tripathi SK, Dhugga KS, Gill KS, et al. Genetic diversity study of cluster bean (Cyamopsis tetragonoloba (L.) Taub) landraces using RAPD and ISSR markers. Int J Adv Biotechnol Res. 2013;4: 460-71.

13. Kuravadi NA, Tiwari PB, Tanwar UK, Tripathi SK, Dhugga KS, Gill KS, et al. Identification and characterization of EST-SSR markers in cluster bean (Cyamopsis spp.). Crop Sci. 2014;54:1097-102.

14. Sharma P, Kumar V, Raman KV, Tiwari K. A set of SCAR markers in cluster bean (Cyamopsis tetragonoloba L. Taub) genotypes. Adv Biosci Biotechnol. 2014:5:131-41.

15. Kumar S, Parekh MJ, Patel CB, Zala HN, Sharma R, Kulkarni KS, et al. Development and validation of EST-derived SSR markers and diversity analysis in cluster bean (Cyamopsis tetragonoloba). J Plant Biochem Biotechnol. 2016;25:263-9.

16. Tanwar UK, Pruthi V, Randhawa GS. RNA-Seq of guar (Cymopsis tetragonoloba, L. Taub.) leaves: De novo transcriptome assembly, functional annotation and development of genomic resources. Front Plant Sci. 2017;8:91.

17. Rawal HC, Kumar S, Amitha Mithra SV, Solanke AU, Nigam D, Saxena S, et al. High quality unigenes and microsatellites markers from tissue specific transcriptome and development of a database in clusterbean (Cymopsis tetragonoloba (L.) Taub.). Genes. 2017:8:313.

18. Hiremath PJ, Kumar A, Penmetsa RV, Farmer A, Schlueter JA, Chamarthi SK, et al. Large-scale development of cost-effective SNP marker assays for diversity assessment and genetic mapping in chickpea and comparative mapping in legumes. Plant Biotechnol J. 2012;10:716-32

19. Vishwakarma MK, Kale SM, Sriswathi M, Naresh T, Shasidhar Y, Garg V, et al. Genome-wide discovery and deployment of insertions and deletions markers provided greater insights on species, genomes and sections relationships in the genus Arachis. Front Plant Sci. 2017;8:2064.

20. Sato S, Nakamura Y, Kaneko T, Asamizu E, Kato T, Nakao M, et al. Genome structure of the legume, Lotus japonicus. DNA Res. 2008;15:227-39.

21. Schmutz J, Cannon SB, Schlueter J, Ma J, Mitros T, Nelson W, et al. Genome sequence of the palaeopolyploid soybean. Nature. 2010;463:178-83.

22. Young ND, Debellé F, Oldroyd GE, Geurts R, Cannon SB, Udvardi MK, et al. The Medicago genome provides insight into the evolution of rhizobial symbioses. Nature. 2011;480:520-4.

23. Varshney RK, Chen W, Li Y, Bharti AK, Saxena RK, Schlueter JA, et al. Draft genome sequence of pigeonpea (Cajanus cajan), an orphan legume crop of resource-poor farmers. Nat Biotechnol. 2011;30:83-9.

24. Varshney RK, Song C, Saxena RK, Azam S, Yu S, Sharpe AG, et al. Draft genome sequence of chickpea (Cicer arietinum) provides a resource for trait improvement. Nat Biotechnol. 2013;31:240-6.

25. Jain M, Misra G, Patel RK, Priya P, Jhanwar S, Khan AW, et al. A draft genome sequence of the pulse crop chickpea (Cicer arietinum L.). Plant J. 2013;74: $715-29$.

26. Wang Z, Li J, Luo Z, Huang L, Chen X, Fang B, et al. Characterization and development of EST-derived SSR markers in cultivated sweetpotato (Ipomoea batatas). BMC Plant Biol. 2011;11:139.

27. Wang Z, Yu G, Shi B, Wang X, Qiang H, Gao H. Development and characterization of simple sequence repeat (SSR) markers based on RNAsequencing of Medicago sativa and in silico mapping onto the M. truncatula genome. PLoS One. 2014;9:e92029.

28. Cordeiro GM, Casu R, McIntyre CL, Manners JM, Henry RJ. Microsatellite markers from sugarcane (Saccharum spp.) ESTs cross transferable to erianthus and sorghum. Plant Sci. 2001;160:1115-23.

29. Ghosh D, Xu J. Abiotic stress responses in plant roots: a proteomics perspective. Front Plant Sci. 2014;5:6.

30. Trakhtenberg EF, Pho N, Holton KM, Chittenden TW, Goldberg JL, Dong L. Cell types differ in global coordination of splicing and proportion of highly expressed genes. Sci Rep. 2016;6:32249. 
31. Nakasugi K, Crowhurst RN, Bally J, Wood CC, Hellens RP, Waterhouse PM. De novo transcriptome sequence assembly and analysis of RNA silencing genes of Nicotiana benthamiana. PLoS One. 2013;8:e59534.

32. Parra G, Bradnam K, Korf I. CEGMA: a pipeline to accurately annotate core genes in eukaryotic genomes. Bioinformatics. 2007;23:1061-7.

33. Parra G, Bradnam K, Ning Z, Keane T, Korf I. Assessing the gene space in draft genomes. Nucleic Acids Res. 2009;37:289-97.

34. Andrews, S. 2010. FastQC: A quality control tool for high throughput sequence data. Available online at: http://www.bioinformatics.babraham.ac. uk/projects/fastqc/

35. Li W, Godzik A. Cd-hit: a fast program for clustering and comparing large sets of protein or nucleotide sequences. Bioinformatics. 2006;22:1658-9.

36. Van Bel M, Proost S, Van Neste C, Deforce D, de Peer YV, Vandepoele K TRAPID: an efficient online tool for the functional and comparative analysis of de novo RNA-Seq transcriptomes. Genome Biol. 2013:14:R134.

37. Moriya Y, Itoh M, Okuda S, Yoshizawa AC, Kanehisa M. KAAS: an automatic genome annotation and pathway reconstruction server. Nucleic Acid Res. 2007;35:182-5

38. Untergasser A, Cutcutache I, Koressaar T, Ye J, Faircloth BC, Remm M. Primer3-new capabilities and interfaces. Nucleic Acid Res. 2012;40:e115.

39. Langmead B, Salzberg SL. Fast gapped-read alignment with bowtie 2. Nat Methods. 2012:9:357-9.

40. Li H, Handsaker B, Wysoker A, Fennell T, Ruan J, Homer N, et al. The sequence alignment/map format and SAMtools. Bioinformatics. 2009;25: 2078-9.

41. Soleimani VD, Baum BR, Johnson DA. Efficient validation of single nucleotide polymorphisms in plants by allele-specific PCR, with an example from barley. Plant Mol Biol Report. 2003;21:281-8.

42. Love Ml, Huber W, Anders S. Moderated estimation of fold change and dispersion for RNA-seq data with DeSeq2. Genome Biol. 2014;15:550

Ready to submit your research? Choose BMC and benefit from:

- fast, convenient online submission

- thorough peer review by experienced researchers in your field

- rapid publication on acceptance

- support for research data, including large and complex data types

- gold Open Access which fosters wider collaboration and increased citations

- maximum visibility for your research: over $100 \mathrm{M}$ website views per year

At $\mathrm{BMC}$, research is always in progress.

Learn more biomedcentral.com/submissions 